\title{
DOMOV A NÁVRATY OSOB PŘEMÍSTĚNÝCH BĚHEM DRUHÉ SVĚTOVÉ VÁLKY (DISPLACED PERSONS)
}

\author{
JANA KASÍKOVÁ \\ Ústav českých dějin FF UK \\ jani.kasikova@gmail.com
}

\begin{abstract}
Home and Returns of the Persons Transfered During the World War II (Displaced Persons)

Population transfers during World War II caused the uprooting of millions of people (Displaced Persons) from their homes. Years of imprisonment in concentration camps, in forced labor or exile have left an indelible mark on the lives of individuals. During the time of displacement, their memories of home and the hope for return were often encouraging, if not essential to survival. This article outlines the perceptions of the home during the war, the reality of post-war returns and observes the transformation of "home" in this dramatic time and its presentation by individuals and institutions.
\end{abstract}

Keywords: displaced Persons - post-war repatriation - perception of home - transformation of home

\section{Přehrávám si sonátu \\ Z hedvábných a dưvěřivých slov \\ Tak jemně a tak tiše \\ Jako když vzpomínám na domov. ${ }^{1}$}

Osoby přemístěné během druhé světové války byly ze svých domovů mnohdy nuceně vykořeněny. $\mathrm{Na}$ jejich př́ikladu se vnímání, význam i role domova a zázemí (nejen) v tomto dějinném období mimořádně projevuje. Následující studie nahlédne problém z historické perspektivy, jednak v politickém a sociálním dobovém kontextu, jednak subjektivním pohledem samotných aktérů.

Války obecně znamenají hluboký zásah do společnosti. Druhá světová válka mimo jiné způsobila nebývalý rozsah přesunů různých skupin osob. Svou roli přitom sehrály nejen válečné operace, ale i nacistická hospodářská a rasová politika. Počet přemístěných osob (Displaced Persons) sahal v celé Evropě do desítek milionů. ${ }^{2}$ Dle obecné mezinárodní defi-

1 Verše básníka Jiř́ho Karena, které vznikly během jeho nuceného pracovního nasazení za druhé světové války. Jiří Karen, Dopisy z rajchu, Praha 2006, s. 37.

2 Současné odhady počtu Displaced Persons se pohybují okolo 10-20 milionů, zatímco dřívější údaje pracovaly s údajem 50-60 milionů osob přemístěných v rámci celkových transferů v období kolem války. Eugene M. Kulisher, Europe on the move: war and population changes, 1917-47, New York 1948, s. 304. 
nice byly Displaced Persons osoby přemístěné v důsledku válečných událostí mimo své domovy, at už v rámci vlastních hranic, nebo častěji mimo svou vlast. ${ }^{3} \mathrm{~V}$ historii migračních pohybů představují tyto přesuny významnou, ačkoli značně specifickou kapitolu. Jednak jsou zde výrazné faktory vynucené migrace a dopadu na různé sociální skupiny obyvatel, jednak předpokládaná dočasnost. ${ }^{4}$ Starosti přidělávaly transfery rovněž Spojencům, protože se předpokládalo, že se několik milionů osob bude nacházet mimo své domovy i po skončení konfliktu a že se budou chtít domů co nejdříve vrátit. ${ }^{5}$ Jejich bezprizorní pohyb po válkou zdevastovaném kontinentě představoval mnohá rizika, zejména zdravotní, ale i zásobovací či kriminální, měl být proto v co nejvyšší míře organizován. Problémem se proto začali Spojenci zabývat ještě v průběhu války. Tuto péči o Displaced Persons na okupovaném území a takzvanou repatriaci zajištovaly mezinárodní orgány a vojenské jednotky. V jednotlivých státech vznikly organizace mnohdy na vládní úrovni. V Československu byl tímto úkolem pověren repatriační odbor pod ministerstvem ochrany práce a sociální péče, který rovněž koordinoval pomoc repatriantům ze strany spolků a veřejnosti. ${ }^{6}$

\section{Přesunuti mimo domov a vnímání domova}

Status Displaced Person představoval velmi heterogenní kategorii zahrnující jak mladistvé nasazené na nucené práce, tak i vězně koncentračního tábora nebo politiky v exilu. Každý z nich svou situaci vnímal samožrejmě odlišně, měl jiné životní podmínky během války a po jejím skončení odlišnou výchozí situaci. Nicméně domov vzdálený i ztracený, jako vzpomínka, jako pŕíčina smutku a obav, ale i touhy a naděje na návrat, se objevuje napříč všemi skupinami. Pokusíme se podívat na jednotlivé kategorie přemístěných z perspektivy domova a jeho vnímání, ačkoli zkušenost každého jednotlivce byla jedinečná a půjde proto o značnou schematizaci.

Masivní přesuny byly způsobeny v Evropě nasazením na nucené práce. Protektorát Čechy a Morava představoval významný zdroj pracovní síly, počet nasazených je odhadován na několik set tisíc osob. ${ }^{7}$ Často se jednalo o dočasnou službu, někdy i částečně nastoupe-

3 Archiv ministerstva zahraničních věcí, fond Londýnský archiv - důvěrný, kart. č. 200, Suggested Classification of Displaced Persons.

4 Migrační teorie zkoumají vlivy v původním místě mající jedince k rozhodnutí o migraci (push faktory) a okolnosti rozhodnutí o destinaci cesty (pull faktory). Pro Displaced Persons byly typické vnější push faktory vynucující přesun jedince. Dle Kunzovy klasifikace šlo zejména o síly aktivní (represivní aparát), ale i pasivní (setrvání v exilu a odmítnutí návratu do okupované vlasti z důvodu strachu z perzekuce). Egon F. Kunz, The Refugee in Flight: Kinetic Models and Forms of Displacedment, in: Robin Cohen (ed.), Theories of migration, Cheltenaham 1996, s. 61-82.

Migrace též souvisejí s kategorií domova. Např. dle encyklopedie Sociologického ústavu AV ČR je pod pojmem domov poznamenáno, že „,Migrací získává člověk během života více domovư a vnímá tedy tento pojem méně osudově. " V tomto ohledu je př́pad Displaced Persons odlišný, protože destinaci nepovažovali většinou za nový domov. Heslo „domov“: https://encyklopedie.soc.cas.cz/w/Domov, vyhledáno 14. 10. 2019.

5 Odhadovalo se, že se po skončení války mimo své domovy bude nacházet asi 12 milionů osob. Corine Defrance - Juliette Denis - Julia Maspero (eds): Personnes déplacées en Allemagne occupée et guerre froide, Bruxelles 2015, s. 12.

6 Viz Jana Kasíková, At' mohou príjeti. Organizace poválečné repatriace a návratů 1942-1947, Praha 2017.

7 Tradičně se uvádělo 640 tisíc nasazených, dnešní odhady se kloní k nižšímu počtu 400-600 tisíc osob. Tomáš Jelínek, Nucená práce v nacionálním socialismu, in: „Nepřichází-li práce k tobě...“, Praha 2004, s. $16-32$. 
nou dobrovolně, ve většině př́ípadů však nucenou, a to zejména v období takzvané totální války od roku 1943, kdy byly uvolňovány „přebytečné pracovní síly“ a zaměstnávány ve válečném průmyslu. Obyvatelstvo také citlivě vnímalo takzvané ročníkové akce, kdy byly na práci nasazovány celé ročníky mládeže ve věku okolo 20 let. „Hlavně jsme psali domů, aby nám poslali něco k jídlu. Občas přišel bochník chleba. " "Dopisy vỉbec byly naše vášeň. (...) Večer (...) první z nás, která vešla, hned hlasitě tř́dila vždy pečlivě připravenou do-

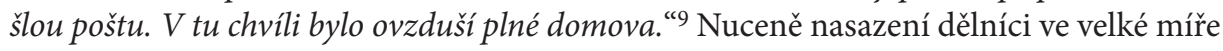
udržovali kontakt $\mathrm{s}$ domovem, $\mathrm{z}$ domova jim byly posílány balíčky s přilepšením a na omezenou dobu jezdili domů na dovolenou. Přemístění bylo považováno za dočasné, počítalo se s návratem a domov (reprezentovaný i rodinnými příslušníky, zejména rodiči) zůstával jistým bodem v nejisté době.

Další podstatnou skupinu přemístěných představovali vězni koncentračních táborů deportovaní z rasových, politických či sociálních důvodů. ${ }^{10}$ Domov jako zázemí někdy opouštěly celé rodiny a jedinec jej tak prakticky ztrácel. V různých projevech se vězni v koncentračních táborech $\mathrm{k}$ domovu upínali, nejen $\mathrm{k}$ tomu současnému, ale i k domovu svého dětství. Pod domovem vnímali také vlast, rodnou krajinu a zejména své blízké. „Piji tě, piji, - krajino moje, - Piji tě jako omamné víno - Velikým douškem, skoro až na dno Piji tě, moje domovino! (...) Čechy mé zlaté, proč miluji vás? - To teprve žalář, koncentrák učí! - ,Zde domov můj 'velebnou písní - Celý kraj rodný duši mou zvučí."11 Vzpomínky na domov i na rodinné příslušníky, kteří v něm zůstali, představovaly v krutých podmínkách zásadní motivaci k životu. „Po práci, když se setmí - domova vzpomínáš: - Co dělá žena s dětmi - a statek rodný náš? (...) V tom slétly se jak ptáče - v tvé oči krůpěje. - To v srdci ženy pláče - stesk, touha, naděje!"12

Rovněž osoby, které odešly do emigrace, respektive exilu, ${ }^{13}$ zejména před hrozbou perzekuce, doufaly $\mathrm{v}$ dočasnost svého odchodu $\mathrm{z}$ domova a upínaly se k němu ve svých vzpomínkách, zejména pak na své blízké. Mnozí z nich svou rodinu zanechali ve vlasti, prožívali proto obavu z jejího možného pronásledování, neměli o svých blízkých zprávy či o jejich deportaci již věděli. Politik Ladislav Feierabend ve svých pamětech poznamenal: „vyčerpávaly mě starosti o osud rodiny a rozhodování, zda se mám vrátit, či zưstat v exilu“. ${ }^{4}$ Obavu měl zejména o svou ženu, která byla za války, stejně jako rodinní příslušníci dalších exilových československých politiků, perzekvována: „[A]č jsem nikdy nepřestal doufat a vnitřní hlas mi při modlitbách šeptal, že je naživu a že se doma shledáme“.15 Na rozdíl od předchozích dvou skupin se však častěji objevuje tendence (i podmínky) vytvářet nový domov na místě dočasného pobytu, který se pro některé stal následně domovem trvalým.

\footnotetext{
8 Jana Havlíková, Místo určení: Sársko: čeští nuceně nasazení vzpomínají, Praha 2004, s. 46.

9 Stanislava Zvěřinová, Devatenáct nám bylo pryč, Praha 2001, s. 48.

$10 \mathrm{~V}$ českých zemích se deportace do táborů dotkly několika desítek tisíc osob, literatura k tématu je roztř́ššěná dle perzekvované skupiny (Židé, Romové, političtí a kulturní představitelé, studenti ad.).

11 Jan Š. Nepomuk, Zpěvy z Dachau, Týn nad Vltavou 1946, s. 28.

12 Báseň vznikla roku 1942 v táboře Sachsenhausen. J. Písecký, Rodný statek, in: Jaroslav Malý - Josek Melichar (eds), Dachau, symbol české síly, vzdoru a oběti: novinářský dokument českých politických vězňủ z doby od 29. dubna do 21. května 1945, Praha 1945, s. 31.

13 Emigraci zde chápeme jako odchod z vlasti, přičemž výrazem exil je zdůrazněn předpoklad dočasnosti tohoto pobytu. K pojmům migrací viz Zdeněk Nešpor, České migrace 19. a 20. století a jejich dosavadní studium, Soudobé dějiny XII, č. 2, 2005, s. 245-284.

14 Ladislav Feierabend, Politické vzpomínky III, Brno 1996, s. 239.

15 Ibidem.
} 
Dalšími skupinami přemístěných byli například utíkající před frontou. Ačkoli pohyby armád obecně nebyly do pohybů Displaced Persons zahrnovány, najdeme zde skupinu, která pod péči orgánů mohla spadnout, a to válečné zajatce. U nich byla zejména prošetřována jejich činnost za války a nárok na návrat. Podobně jako jiní vojáci, domov opouštěli s nadějí, ale i s nejistotou návratu. ${ }^{16}$ Mezi další skupiny přemístěných patří vysídlení na území Protektorátu z několika oblastí, a to zejména za účelem vybudování vojenských cvičišț. ${ }^{17}$ Protože se jednalo o venkovské oblasti, obyvatelé opouštěli rodové usedlosti, což pro ně byla citelná ztráta. $\mathrm{V}$ důsledku války byly některé rodiny, zejména národnostních Němců z východní Evropy, usazovány za zvýhodněných podmínek jako kolonisté na obsazená území. Jejich snahou tedy bylo vytvořit nové domovy, místním obyvatelstvem však byli tito takzvaní národní hosté těžko přijímáni a se skončením války je spolu s německým obyvatelstvem čekalo vysídlení. ${ }^{18}$

Myšlenky a vzpomínky na domov, at už současný ve vlasti, nebo minulý v dětství, dodávaly v každé z výše uvedených situací lidem sílu a naději na návrat. Většinou se vztahovaly k prostoru, lidem (manželce, rodičům, dětem), ale i událostem (Vánoce, školní docházka). V projevech všech zmíněných skupin se domov neustále objevuje a skloňuje $\mathrm{v}$ různých souvislostech. Zvláštní pozornost byla věnována ženám, které v tomto kontextu můžeme chápat také jako představitelky rodinného krbu. ${ }^{19}$ Často byla představa spojována také s vlastí jako takovou, protože se přemístěné osoby nacházely namnoze v zahraničí. ${ }^{20}$

\section{Návrat domů [obr. 1 a 2]}

Po skončení války byla na mezinárodním poli organizována repatriace, tedy doslova návrat do vlasti, $\mathrm{v}$ přeneseném slova smyslu návrat domů. ${ }^{21}$ Plánování péče o Displaced Persons a jejich repatriaci řešili představitelé spojeneckých států již od roku $1943 \mathrm{v}$ rámci př́pravy poválečné obnovy. Jednání se záhy přesunula na půdu UNRRA, která disponovala prostředky i personálem. ${ }^{22} \mathrm{~S}$ vlastní iniciativou přišly i vojenské jednotky Vrchního velitelství spojeneckých vojsk (SHAEF). Postupně obě instituce upravily své kompetence

16 Někteří zajatí vojáci Wehrmachtu se dostali do československých zahraničních jednotek. Mnohdy se jednalo o vojáky původem z pohraničních československých oblastí. Jaroslav Vaculík, Poválečná repatriace československých, tzv. prememístěných osob: (Displaced Persons), Brno 2004, s. 41.

17 Vysídlena tak byla část obyvatel Benešovska-Neveklovska, na Moravě pak Vyškovska. Dle dlouhodobějších plánů šlo o systematickou germanizaci území. Viz Tomáš Zouzal, Zabráno pro SS: zřízení výcvikového prostoru Böhmen v letech 2. světové války, Praha 2016.

18 Adrian von Arburg - Tomáš Staněk (eds): Vysídlení Němců a proměny českého pohraničí 1945-1951, II. 1, Středokluky 2011, s. 73-74.

19 Symbolika ženy byla natolik silná, že po válce vznikla iniciativa pro vybudování pomníku těm, které udržely v době neprítomnosti svých mužů chod domácnosti a v době perzekuce jim dodávaly naděje i podpory.

20 Mezi přemístěnými se projevilo silné prožívání pražského povstání, o kterém se dozvěděli skrze poslech rozhlasu, někteří se dokonce přes zákaz vydali do Prahy pomáhat při bojích.

21 Organizace byla velmi náročná, probíhala na válkou zničeném kontinentě, za omezených prostředků a všemi směry. $Z$ těchto a dalších, zejména politicko-ekonomických důvodů, se protáhla na několik týdnů i měsíců. K celkové organizaci viz např. Ben Shephard, The Long Road Home, The Aftermath of the Second World War, New York 2011.

22 Organizace Spojených národů pro pomoc a obnovu (United Nation Relief and Rehabilitation Administration - UNRRA) byla založená 9. listopadu 1943. Prostředky pro obnovu válkou postižených 
tak, že SHAEF přebíralo obecnou organizaci Displaced Persons, zatímco UNRRA zajištovala personál a péči. Mimoto byla vytvořena sít mezistátních repatriačních dohod a vysláni repatriační styční důstojníci. Jejich úkolem bylo zajistit příslušníky vlastního národa a organizovat jejich repatriaci. Čechoslováci se nacházeli ve velkém množství v zemích hraničících s obnoveným Československem, toužili vrátit se domů co nejrychleji, volili proto mnohdy samostatný návrat, takzvanou samorepatriaci. ${ }^{23}$ Tento fenomén představoval problém pro úřady, které se prostřednictvím evidence i benefitů snažily i tyto repatrianty zpětně podchytit.

Podobně jako pro každého nebyla stejná východiska, lišil se i tento návrat. Dle „ideální varianty měly Displaced Persons vyčkat instrukcí ve shromaždovacích centrech pro ně určených (tzv. DP-Camps), odkud byly oficiálními transporty či kolonami převezeny do vlasti, v Československu zejména do Plzně, Českých Budějovic či Prahy. Odsud pak, pokud nebyla nutná lékařská péče či karanténa, jim byla umožněna cesta do domovů, přičemž repatriantům bylo poskytnuto stravné na dobu sedmi dní, stejně tak bezplatné jízdné. I poté mohli repatrianti využívat různých výhod, např́iklad ozdravných pobytů, rozdělování bytů, přednostního získávání majetku v pohraničí a podobně. $\mathrm{V}$ takovém př́padě se československé Displaced Persons skutečně dočkaly „štastného návratu“.

Objevovaly se však četné a různorodé problémy, pro mnohé se tak stal návrat komplikovaný. Nesnáze se mohly objevit již při oficiálním procesu repatriace (časté poruchy transportních prostředků, okradení, špatná organizace ad.). Ani poté, co se však jedinec vrátil domů, nemusel shledat domov, v jaký doufal. Jednak to mohla být bolestná ztráta rodinných příslušníků (někdy dokonce všech) a dalších známých. Pátrací dotazy byly jedny z nejsledovanějších a pátrací služba se postupně rozvinula do propracované organizace spolupracující se vznikajícími mezinárodními pátracími orgány. ${ }^{24}$ Dále nastávaly situace, kdy se navrátilec nemohl vrátit do původního domova, protože ten již měl nové obyvatele, kteří jej z nejrůznějších důvodů neuvolnili. Nechvalně známé je také odmítnutí vrácení uschovaného či arizovaného majetku, nemovitostí či podniků. Sociální averze dostoupila $v$ některých př́padech takové intenzity, že přiměla navrátilce opětovně opustit vlast a odejít do emigrace. Toto byl zejména případ židovského obyvatelstva, ${ }^{25}$ ovšem nejen v Československu. ${ }^{26}$

zemí do ní přispívaly členské země nezasažené válkou př́mo ze svého HDP. Karel Sommer, UNRRA a Československo, Opava 1993.

23 Samorepatriace byla rozšířená zejména $\mathrm{z}$ východní okupační zóny spravované Rudou armádou, kde organizace repatriace probíhala na základě dohod s veliteli a ne jednotně se západními okupačními zónami.

${ }^{24}$ Orgán, který převzal pátrací agendu i péči o uprchlíky po zániku UNRRA, byla Mezinárodní organizace pro uprchlíky (International Refugee Organization). Archiv v Bad Arolsenu vzniklý z centrální pátrací kartotéky je dodnes cenným zdrojem dokumentů k celé problematice.

25 Židé také mnohdy mluvili německy, což v kontextu poválečných protiněmeckých nálad zvyšovalo nevraživost vi̊či nim a byli společně s Němci zařazováni k odsunu. Vláda oficiálně židovskou národnost neoddělovala, preferovala tzv. asimilaci v rámci československé společnosti. Na druhou stranu právě u Židů podporovala jinak omezené vystěhovalectví. Archiv bezpečnostních složek, fond 425, složka 369-3, jednání z meziministerských porad o vystěhovalectví z Ceskoslovenska. K mediálním diskurzům poválečné doby viz Christiane Brenner, Mezi Východem a Západem: české politické diskurzy 1945-1948, Praha 2015, k problematice odsunů viz Adrian von Arburg - Tomáš Staněk, Vysídlení Němců a proměny českého pohraničí 1945-1951, Praha 2010 a 2011.

26 Známé jsou např̀. protižidovské pogromy v Polsku, které podnítily masivní poválečnou emigraci polských Židů, zejména do Palestiny. Cást z nich přitom přecházela také přes území Československa. Viz Jiř́ Friedl, Domů, a za svobodou, Praha 2020. 
V československém př́ípadě docházelo ještě za hranicemi k četnému odmítnutí návratu jednotlivců i celých skupin. Československo od počátku vyjednávání v exilu odmítalo repatriaci Němců a Mad’arů a tuto podmínku přes komplikace prosadilo i do mezistátních repatriačních smluv. Československý repatriační styčný důstojník měl právo na rozhodnutí o vydání víza, pravidlem obvykle bývala národnost, za jakou se repatriant sám považoval, prrípadně mateřská řeč a další doklady. ${ }^{27} \mathrm{~V}$ prrípadě německé a madarské národnosti bylo vydání víza odmítnuto a osoby předány do kompetence jiných úřadů (vesměs zajištujících péči o odsunuté Němce). Jednotlivě se také posuzovaly takzvané sporné př́pady, zejména válečných zajatců, kde se opět řešila národnost dotyčného a jeho aktivita za války. Žadatelé se odvolávali při žádosti o návrat do Československa na svou rodinu, vazby či pročeskoslovenské aktivity, ne vždy jim však bylo vyhověno. ${ }^{28}$ Neúspěšní žadatelé byli předáváni úřadům zajištujícím odsunuté obyvatelstvo. ${ }^{29}$ Pro tyto lidi tedy následující roky znamenaly složité budování nejen nového domova, ale přijetí nové vlasti.

Ojediněle odmítali návrat i Čechoslováci (respektive ti, jejichž národnost byla jako taková uznána), a to $\mathrm{z}$ několika důvodů. ${ }^{30} \mathrm{~V}$ cizině zůstala část politické opozice, rovněž politici demokratických stran zažívali útisk při snaze o návrat či se do Československa vrátili jen dočasně. ${ }^{31}$ Důvody byly rovněž osobní, např́íklad sňatek v zahraničí a vybudování nového domova či původní domov v zahraničí v př́ípadě krajanů.

\section{Nový domov}

Převratné období konce války způsobilo, že různé skupiny hledaly či budovaly nový domov. Zmínili jsme již německé obyvatelstvo, osoby, které se rozhodly zůstat v exilu, či navrátilce, kteří opětovně odcházeli z vlasti. Nový domov budovali i mnozí „štastní navrátilci“, mezi nimi si vezměme za prŕklad mladé lidi z nuceného nasazení, kteří nové domovy zakládali jako další přirozenou etapu svého života, ovšem za mimořádných okolností. Perzekvovaní také měli přednostní nárok na příděl nemovitosti v pohraničí, jiní si přivedli z válečného období své životní partnery, zejména mezi nuceně nasazenými či lidmi v exilu.

Zvláštní kapitolou, a to v celosvětovém kontextu, byly děti. Mezinárodně se řešil problém takzvaných bezprizorních nebo nedoprovázených dětí, tedy těch, které často prošly koncentračním táborem a neměly žádného rodiče ani jiného př́buzného. ${ }^{32} \mathrm{Za}$ války

27 Vláda za tímto účelem schválila v listopadu 1944 a únoru 1945 instrukce repatriačním styčným důstojníkům pro udělování víz, kde vymezila kritéria pro uznání československé národnosti. Jan Němeček - Ivan Stovíček - Helena Nováćková et al., Zápisy se schủzí československé vlády v Londýně [1945], Praha 2016, s. 285-288.

28 Vojenský ústřední archiv - Vojenský historický archiv, fond Koncentrační tábory, kart. č. 21, složka $97 / \mathrm{Da} / 1 / 21$.

29 Na území Německa to nebyly mezinárodní orgány, ale německé úřady.

${ }^{30} \mathrm{Na}$ rozdíl od jiných národností nebyly př́ odmítání repatriace výrazné důvody ekonomické.

31 Návrat byl dle některých svědectví zdržován podle dikce komunistické strany ve vlasti. Někteří z demokratických politiků, např. Ladislav Feierabend či Petr Zenkl, zvolili opětovný exil po roce 1948. Jan Němeček, Likvidace československé exilové vlády v Londýně, in: Rok 1945 v českých a evropských dějinách, Praha 2002, s. 71-82.

32 Viz k problematice Tara Zahra, The lost children: reconstruction Europe's families after World War II, Cambridge 2011. 
se v rámci programů germanizace množství dětí dostalo do pěstounských německých rodin. Jejich opětovný návrat byl pro mnohé z nich spíše než návratem novým vykořeněním. ${ }^{33} \mathrm{~V}$ Československu bylo pro děti obětí nacistické perzekuce zřízeno několik dětských domovů. ${ }^{34}$ Některé děti židovské národnosti získaly péčí mezinárodních židovských organizací nový domov v USA či Palestině. Jejich nový domov byl tedy diametrálně odlišný od původního.

\section{Propagace domova [obr. 3]}

Obraz domova byl také využit při vládní propagaci, která sháněla pomoc (zejména finanční a materiální) pro takzvanou repatriační akci. Protože úřady v chaosu doby nezvládaly veškerou péči, podchytily navracející se Displaced Persons ve velké míre nevládní dobrovolné organizace (Československý červený křiž, Charita, České srdce a další), které s repatriačním odborem záhy úzce spolupracovaly. ${ }^{35}$ Ve velké míře však participovala také veřejnost obecně, uvědomíme-li si, že při počtu 700000 repatriantů se tento problém dotkl významné části obyvatel. ${ }^{36}$ Byly pořádány mnohé materiální i finanční sbírky, ke kterým byla veřejnost vyzývána skrze apel na umožnění „návratu domů“ “ ${ }^{37}$ Do propagace se zapojily rovněž známé osobnosti, při sbírce benzinu se v několika médiích objevila báseň Jaroslava Seiferta, končící výzvou: „Všechny je chceme míti doma - z babylonského zajetí! - Darujte benzin, benzin kdo má - at mohou prijeti!“38

Repatriační odbor také vydával do konce roku 1945 vlastní tisk Služba repatriantům, který v počátcích sloužil zejména jako platforma pro informování o jménech navrátilců, případně pro pátrací dotazy. Objevovaly se zde však i další rubriky, jako byly inzeráty, informativní články či obecně zprávy, které postupně začaly převažovat. Na začátku podzimu sbíral tisk zpětnou vazbu od čtenářů, přičemž první dvě otázky, "Jste štastni, že jste opět doma?" a „Měli jste starost a obavy o své rodiny?", měly zřejmě vzbudit emoce společné všem skupinám navrátivších se a povzbudit je ke spolupráci s úřadem v oblasti evidence a pátrání. ${ }^{39}$

${ }^{33}$ Některé děti dokonce zůstaly v kontaktu s adoptivními německými rodiči, viz vzpomínky Aleny Veselovské, rozené Šámalové, či v Ležácích narozené Jarmily Doležalové, rozené Štulíkové. Jarmila Doležalová, Osud jménem Ležáky, Včelákov 2017.

34 Bezprostředně po válce zř́dil v Československu několik dočasných domovů pro děti z koncentračních táborů i pro německé děti $z$ internačních táborů Přemysl Pitter v rámci tzv. akce zámky. Zde se jim dostalo nejen základní péče, ale i důležité psychické podpory. Tomáš Pasák, Přemysl Pitter - život pro druhé, Praha 1997, s. 60-101.

35 Národní archiv, fond Ministerstvo práce a sociální péče - repatriace, kart. č. 214, spis Organizace, s nimiž spolupracuje repatriační odbor, či viz Jana Kasíková (pozn. 6), s. 205-221.

36 Tento počet je uváděn dle oficiálních statistik, není však jistá kategorizace navrátilců, z nichž část spadá také mezi tzv. reemigranty, tedy krajany stěhující se do Československa. Část repatriantů naopak nebyla evidována. NA CR, fond MPSP-R, kart. č. 247, sign. R 1319-26/2, Zpráva o činnosti repatriačního odboru.

37 V rámci propagace byl natočen krátký dokumentární film Cesta domů (1946), který zobrazoval „ideální" průběh repatriace od procesu pátrání, přes samotnou cestu do vlasti a péči úradů, po ozdravný pobyt navrátilců.

38 Jaroslav Seifert, Agitka, Služba repatrianti̊m, 1945, č. 24, s. 2.

39 Čtyřri otázky, Služba repatriantům, 1945, č. 44, s. 2. 
Propagace domova jako soukromé záležitosti velmi záhy přešla do propagace budování nové vlasti, respektive nové společnosti. Silná levicová orientace je znatelná nejen z periodik levicových stran. Odhodlání k veřejné angažovanosti se objevuje ve zdravicích vězňů táborů do vlasti, při vzniku Svazu osvobozených politických vězňů, v politických i individuálních projevech. Přímo ve vztahu $\mathrm{k}$ repatriantům se tendence objevuje například v brožuře Jaroslava Šímy (pracovníka repatriačního odboru), který bývalé oběti přirovnává k utrpením očištěným základním kamenům nové společnosti. ${ }^{40}$ Prolínání touhy po domově a po budování nové lepší společnosti je významným fenoménem doby, typickým právě pro perzekvované osoby.

\section{Závěr}

Podíváme-li se na problematiku Displaced Persons z perspektivy „domova“, pozorujeme, že představoval středobod problému. Displaced Persons byly osoby z domova vykořeněné, což tuto jinak silně heterogenní skupinu propojuje. Představa domova, ke které se upínaly naděje přemístěných lidí, se vztahovala bud'k přetrvávajícímu domovu, nebo, a to především, $\mathrm{k}$ blízkým a ke vzpomínkám na štastné chvíle doma. Ve fázi během války bychom mohli nazvat představu jako „stálý domov“, respektive konkrétní neměnný záchytný bod, ke kterému se představy upínaly. Evropa byla v období války i po ní dějištěm několika mohutných migračních vln, od pohybů vojsk přes masivní vysídlování a dílčí stěhování národnostních skupin po zmíněné návraty přemístěných osob. Paralelně k fenoménu „země v pohybu“ 41 bychom toto období mohli nazvat jako „domov v pohybu“, který postihl nevídaný počet lidí, at už se jednotlivci vrátili do původního domova, či budovali domov nový.

Za války a po válce domov figuroval jako mimořádně důležitý element, který držel mnohé jedince doslova při životě. Zvláště v takto extrémních podmínkách se domov a jeho představa výrazně projevil jako základní lidská sociální potřeba. Zároveň válečné přesuny obyvatel způsobily vykořenění z domovů, které jedince i společnost silně poznamenalo. Poválečné období znamenalo v souvislosti s válečnými přesuny, s dynamickými a dramatickými politicko-sociálními okolnostmi, hlubokou proměnu domova pro nebývalý počet i spektrum osob.

\section{SUMMARY}

\section{Home and Returns of the Persons Transfered During the World War II (Displaced Persons)}

During World War II, an unprecedented number of people were unprooted from their homes because of war and because of Nazi economic and racist policies. This study uses

40 Jaroslav Šíma, Sociální obnova, Praha 1945, s. 28.

41 Pod tímto pojmem chápeme četné a prolínající se migrační proudy jak v Evropě, tak např. v pohraničí Československa. 
the example of Displaced Persons to explore the perception, significance and transformation of home in the historical and social context.

The Displaced Person category included heterogeneous groups of people, each perceiving their situation differently, each with different living conditions. However, an idea of a home connected all these groups. Forced deployed persons assumed that their separation from home would be a temporary measure, which remained a reason for their hopefulness during uncertain times. Concentration camp prisoners often lost their homes and family members, but their memories of home, childhood, and homeland also sustained the hope that contributed to their survival. Some people in exile hoped to be reunited with their loved ones, while others set up new homes abroad. The loss of home also affected other groups of DPs - evacuees, colonists, or prisoners of war. Thoughts and memories of home, present or past, gave them strength and kept alive their aspirations to eventually return. These hopes related to place (town, homeland), people (spouse, parents, children), but also events (Christmas).

The longed-for return was supposed to start after the end of the war. Extensive international cooperation had been established between Allied governments, UNRRA and military forces in order to prevent the chaos and health, supply and criminal risks when returning the DPs to their respective homes. Ideally, DPs were supposed to wait for the official transport in one of the many assembly centers. Due to delays, some DPs set out the return home individually, which was the route of choice for many Czechoslovaks.

Returning repatriates were provided with care and other benefits even after returning to their home country. For the authorities to gain support and funds for this so-called repatriation event, the idea of "home" and the emotional attachment to it were used in promotion of these programs in the media (organizing collections, reports, the movie The Way Home). The promotion of the "home" as a private affair soon turned to the promotion of building a new society. This "happy return" was not the case for everyone. Others experienced quite a complicated homecoming, either due to difficulties during the trip or not having their home hoped for. Returning DPs came to find that their loved ones did not survive, their original home already had new inhabitants etc. Some DPs therefore chose to leave their homeland again and build a new home abroad (especially Jews). The national groups of Germans and Hungarians were also denied return home even before the transport itself. Other time they were destined for expulsion. After the war, many of the displaced persons found a new home - in their homeland as they had grown up (young, forced laborers), abroad (in exile, expulsion, emigrants) or were in a new family (unaccompanied children).

Home and its loss (and the hope for a return) was in the very center of the mass relocation. Memories and ideas were fixed on a "permanent home", a secure point of reference. During the war and post-war period, however, there were massive movements of the population, and that has affected the idea of "home" itself. We can point to the phenomenon of "home in motion" affecting an unprecedented number of people. In extreme conditions, the home manifested itself significantly as a basic human and social need. The war-induced uprooting of an individual and the society at large has severely affected what "home" meant, both at the individual level and the societal level. 


\section{VÝBĚROVÁ BIBLIOGRAFIE}

Adrian von Arburg - Tomáš Staněk (eds.), Vysídlení Němců a proměny českého pohraničí 1945-1951, Středokluky 2011.

Robin Cohen (ed.), Theories of migration, Cheltenaham 1996.

Juliette Denis - Julia Maspero (eds), Personnes déplacées en Allemagne occupée et guerre froide, Bruxelles 2015.

Ladislav Feierabend, Politické vzpomínky III, Brno 1996.

Jana Havlíková, Místo určení: Sársko: čeští nuceně nasazení vzpomínají, Praha 2004.

Jana Kasíková Jana, At’mohou přijeti. Organizace poválečné repatriace a návratu 1942-1947, Praha 2017.

Eugene M. Kulisher, Europe on the move: war and population changes, 1917-1947, New York 1948.

Jan Němeček - Ivan Štovíček - Helena Nováčková et al., Zápisy se schůzí československé vlády v Londýně [1945], Praha 2016.

Ben Shephard, The Long Road Home, The Aftermath of the Second World War, New York 2011.

Karel Sommer, UNRRA a Československo, Opava 1993.

Jaroslav Vaculík, Poválečná repatriace československých, tzv. přemístěných osob: (Displaced Persons), Brno 2004.

Tara Zahra, The lost children: reconstruction Europe's families after World War II, Cambridge 2011. 


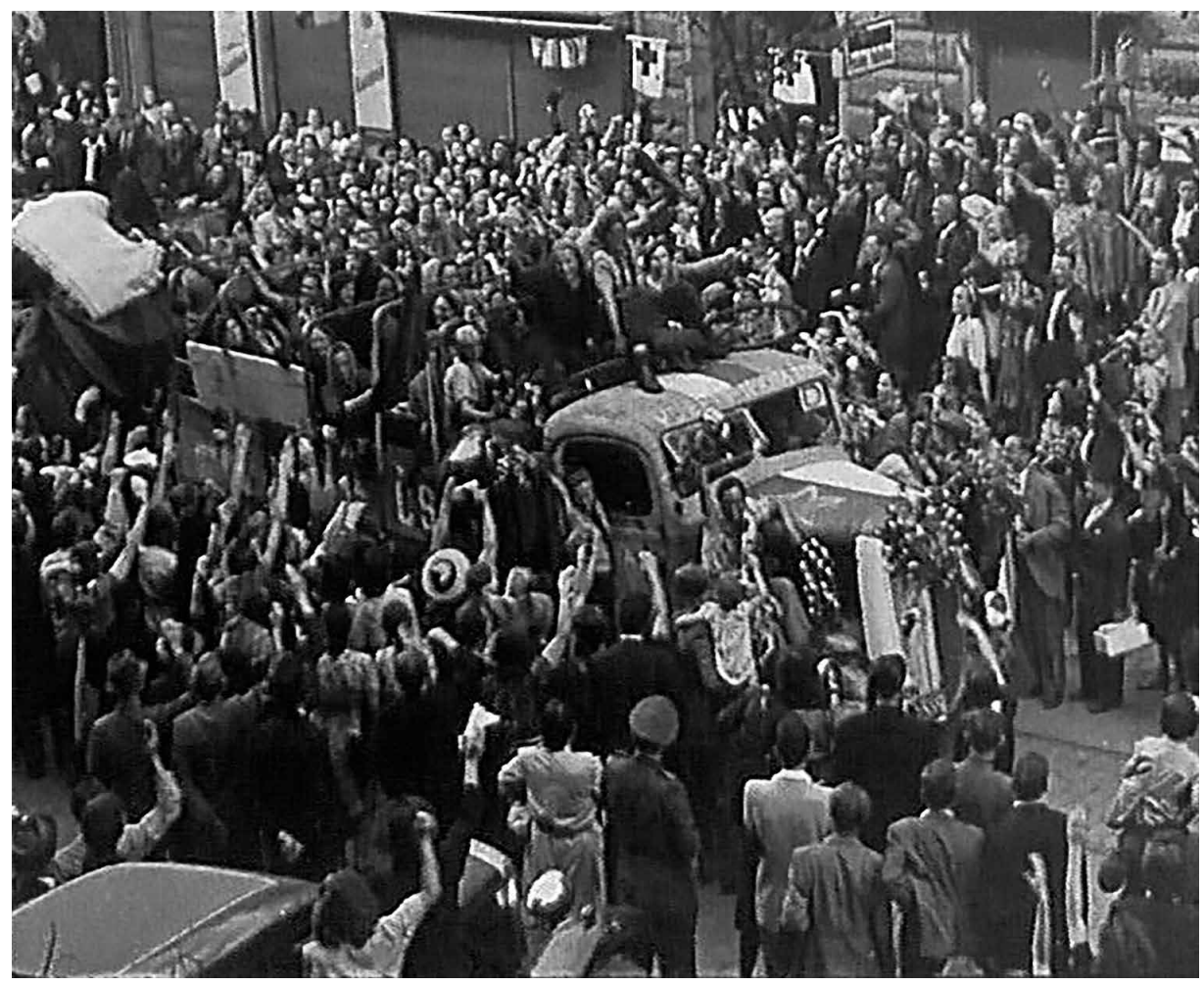

Obrázek 1. Miroslav Tiller, Cesta domů (00:05:46:00), 1945, Národní filmový archiv 


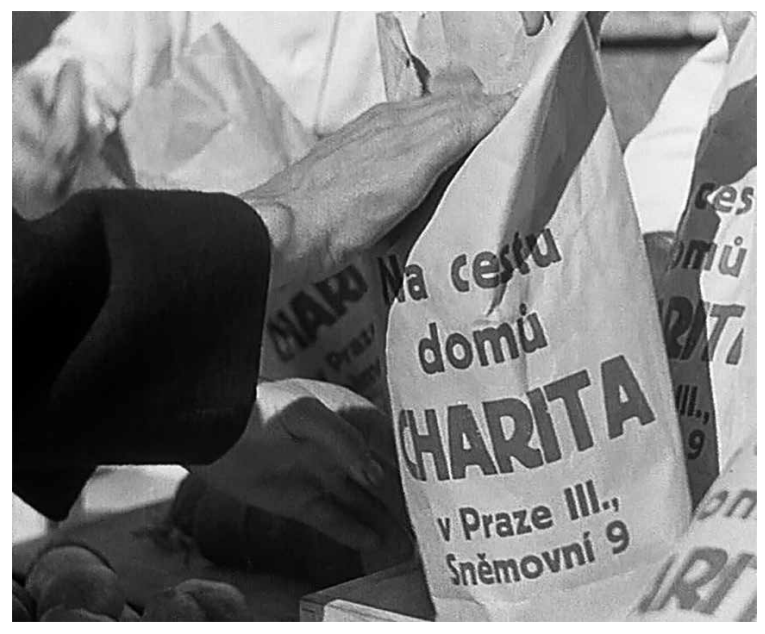

\section{Benzin pro repatrianty}

Pro návrat politických věznù je třeba benzinu. Na výzvu E. F. Buriana se pfední ceští básnici postavill do služeb této akce.

\section{Agitka}

Jaroslav Selfert

Vy, štastní doma $v$ sladkêm kruhu téch, které máte nejradši, nestači píipnout tríbarevnou stuhu, ne, nestačil

Vĩdyt máte dluh, fen vzpomeñte si, dluh nutno zaplatit, vzpomeñte téch, kdo trči kdesi a nemohou se navrátit.

Všechny je chceme miti doma z babylonského zajeti! Darujte benzin, benzin kdo má, at mohou pijjetil
Obrázek 2. Miroslav Tiller, Cesta domů (00:07:17:06), 1945, Národní filmový archiv
Obrázek 3. Jaroslav Seifert, Agitka, Služba repatriantưm č. 24 ze dne 21 . 7. 1945. Snímek Jana Kasíková 